\title{
FREQUENCY OF THE $\triangle$ F508 MUTATION IN 108 CYSTIC FIBROSIS PATIENTS IN SÃO PAULO: COMPARISON WITH REPORTED BRAZILIAN DATA
}

Thelma Suely Okay, Wagner Paes Oliveira, Roberto Raiz-Júnior*, Joaquim Carlos Rodrigues, and Gilda Maria Bárbaro Del Negro

OKAY TS et al. Frequency of the $\Delta$ f508 mutation in 108 cystic fibrosis patients in São Paulo: comparison with reported Brazilian data. CLINICS 60(2):131-134, 2005.

PURPOSE: To analyze the frequency of the delta F508 $(\Delta \mathrm{F} 508)$ deletion mutation in 108 unrelated cystic fibrosis patients and compare the results with the previously reported data for Brazilian patients. Cystic fibrosis is the leading cause of genetic disease in Caucasians, and the $\Delta \mathrm{F} 508$ deletion is the most common mutation associated with the disease.

METHOD: The frequency of the $\triangle \mathrm{F} 508$ mutation was assessed by means of a polymerase chain reaction (PCR) followed by detection in $8 \%$ silver-stained polyacrylamide gels.

RESULTS: Twenty-three of 108 patients (21.3\%) were homozygous for the $\Delta$ F508 deletion, 50 were heterozygous $(46.3 \%)$, and the remaining $35(32.4 \%)$ were non-carriers. In terms of alleles, there were 96 mutated (96/216 or $44.45 \%)$ and 120 wild-type ones $(120 / 216$ or $55.5 \%)$.

CONCLUSION: The $44.45 \%$ of affected alleles that were found is higher than the $33 \%$ first described in 1993 , but slightly lower than the $48 \%$ recently reported. Moreover, our data corroborated the idea that the frequency of the $\Delta \mathrm{F} 508$ mutation is lower in Brazil in comparison to that found in studies carried out in Europe and North American (circa 70.0\%), probably due to increased racial miscegenation. These findings must be taken into account before any genetic screening of the population is proposed in Brazil.

KEYWORDS: CFTR. DF508. Mutation. Deletion. Cystic fibrosis.

Cystic fibrosis (CF) is the most common potentially lethal autosomal recessive disease of Caucasians. The affected gene, CFTR (cystic fibrosis transmembrane conductance receptor), has been determined to code for a chloride channel. Laboratory diagnosis is based on the finding of abnormally high concentrations of chloride in sweat. ${ }^{1}$ The clinical features of $\mathrm{CF}$ are dominated by involvement of the respiratory tract, where obstruction of the airways by thick, sticky mucus and subsequent infection, especially with Pseudomonas species, predominate. In most patients, there is also involvement of the intestinal tract leading to pancreatic insufficiency as a result of obstruction of the pan-

From the Laboratory of Medical Investigation (LIM/36) of the Department of Paediatrics, and the Pneumology Unit of the Child Institute, Hospital das Clínicas, Faculty of Medicine, University of São Paulo - São Paulo/SP, Brazil.

* In memorian

E-mail: tsokay@icr.hcnet.usp.br

Received for publication on December 02, 2004.

Accepted for publication on January 01, 2005. creatic ducts and subsequent scarring and destruction of exocrine function. ${ }^{2}$

The CFTR gene is composed of 250,000 base pairs and 27 exons and encodes a protein of 1,480 amino acids. The finding that one particular mutation, the delta F508 ( $\triangle F 508)$, which is a 3 base-pair deletion in exon 10 of the CFTR gene corresponding to codon 508 (phenylalanine) of the protein, is responsible for up to $70.0 \%$ of all mutations found in CF patients tested so far has made its molecular detection a very attractive diagnostic tool. ${ }^{3}$ However, it has been shown that the frequency of this mutation varies significantly among ethnic groups, ranging from $26.0 \%$ in Turkey to $88.0 \%$ in Denmark. ${ }^{4}$

A few Brazilian studies carried out in the south and southeast regions of Brazil found differences with respect to the frequency of the $\Delta \mathrm{F} 508$ mutation among $\mathrm{CF}$ patients and also in comparison to those reported in European countries and in the USA. ${ }^{5}$ In 24 patients in São Paulo, 33.0\% of alleles were affected; ${ }^{6}$ In 17 patients in Rio de Janeiro, a 
frequency of $35.0 \%$ of affected alleles was found. ${ }^{7}$ In 190 patients from São Paulo, Paraná, and Rio Grande do Sul, $47.0 \%$ had the $\Delta \mathrm{F} 508$ mutation. ${ }^{8}$ In another study of 120 chromosomes of 60 patients in São Paulo, a frequency of $31.7 \%$ of alleles with the $\Delta \mathrm{F} 508$ mutation was found. ${ }^{9}$ In 61 patients from the South of Brazil, $50.8 \%$ of the alleles had the mutation. ${ }^{10}$ Of 44 patients from Rio de Janeiro, $47.7 \%$ were affected, with a frequency of $30.7 \%$ affected alleles $^{11}$ More recently, among 160 Brazilian patients in a study conducted in São Paulo, $48.4 \%$ of alleles were affected, ${ }^{12}$ and in 77 patients from the south of Brazil, $48.7 \%$ of alleles had the $\Delta F 508$ mutation. ${ }^{13}$ Raskin et al. (2004) concluded that the frequency of the $\Delta \mathrm{F} 508$ mutation varies remarkably according to geographic and ethnic origin of patients (Euro-Brazilians or Afro-Brazilians). ${ }^{14}$

\section{PATIENTS AND METHODS}

This study was approved by the Ethics Committee of the Faculty of Medicine, University of São Paulo, Brazil.

One-hundred and eight unrelated clinically and laboratory diagnosed $\mathrm{CF}$ patients were enrolled in this study to determine the frequency of $\Delta \mathrm{F} 508$-mutated alleles in this population. We aimed at comparing our data with those previously reported with respect to Brazilian CF patients. ${ }^{5-13}$

Two milliliters of whole blood samples (EDTA, Becton Dickinson) were drawn from patients after informed consent. DNA extraction was performed according to a previously described salting out protocol. ${ }^{15}$ The presence of the $\Delta$ F508 mutation was determined by means of a classical PCR followed by detection of amplification products in silver-stained polyacrylamide gel electrophoresis according to a previously described protocol, ${ }^{16,17}$ which was modified to fit our laboratory conditions.

DNA samples of non-carrier subjects (having 2 wildtype alleles) yielded a unique 98 bp (base-pair) fragment, whereas samples from heterozygous patients had 2 amplified fragments, 1 of $98 \mathrm{bp}$ and 1 of 95 bp (lacking 3 basepairs), and finally DNA from homozygous individuals had only 1 amplified fragment of $95 \mathrm{bp}$. Amplifications were performed as follows: $10 \mathrm{ng}$ of genomic DNA, $0.4 \mathrm{mM}$ of each of the primers "sense" C16B (5'GTTTTCCTGGATTATGCCTGGGCA-3" and "anti-sense" C16D (5' - GTTGGCATGCTTTGATGACGTTTC); 1.5 mM of $\mathrm{MgCl}_{2}, 2.5 \mathrm{U}$ of Taq DNA polymerase (AmershamPharmacia Biotech). After an initial denaturation step of 5 min. at $95^{\circ} \mathrm{C}, 40$ cycles of amplification were performed in a Minicycler PT-150, (MJ Research). Cycles consisted of 1 min. at $95^{\circ} \mathrm{C}, 1 \mathrm{~min}$. at $55^{\circ} \mathrm{C}$ and $1 \mathrm{~min}$. at $72^{\circ} \mathrm{C}$, and were followed by a final extension step of $5 \mathrm{~min}$. at $72^{\circ} \mathrm{C}$.

Ten microliters of amplification products were analyzed by means of vertical electrophoresis in $8 \%$ polyacrylamide gels under non-denaturing conditions for $4 \mathrm{~h}$ and $30 \mathrm{~min}$. $(25 \mathrm{~mA}, 450 \mathrm{~V}, 20 \mathrm{~W})$ in a refrigerated electrophoresis apparatus (Höefer SE 660, Amersham-Pharmacia Biotech). Then, gels were silver-stained, washed, and fixed according a previously described protocol ${ }^{18}$ and afterwards were dried in a gel dryer (BioRad, USA), at $80^{\circ} \mathrm{C}$ for $2 \mathrm{~h}$ and $30 \mathrm{~min}$.

\section{RESULTS}

Among the 108 patients studied, we found 23 (21.3\%) homozygous for the $\Delta \mathrm{F} 508$ deletion mutation, 50 heterozygous $(46.3 \%)$, and $35(32.4 \%)$ non-carriers. In terms of alleles, there were 96 mutated $(96 / 216$ or $44.45 \%)$ and 120 wild-type ones (120/216 or $55.5 \%)$.

Table 1 summarizes the data of 14 Brazilian studies performed in cystic fibrosis patients according to the number of alleles studied, the region of the country, and the frequency of $\Delta$ F508-mutated alleles. Briefly, the data show that the totality of reports included south or southeast regions patients, with a great variability of either $\Delta \mathrm{F} 508$ mutation frequency as well as other CF-associated mutations (21.0 to $81.0 \%$ ).

Table 1 - Brazilian studies performed in cystic fibrosis patients according to the number of alleles studied, the region of the country, and the frequency of $\Delta \mathrm{F} 508$-mutated alleles.

\begin{tabular}{|c|c|c|c|}
\hline $\begin{array}{l}\text { No. } \\
\text { chromosomes }\end{array}$ & $\begin{array}{l}\text { Region of } \\
\text { Brazil / State }\end{array}$ & $\begin{array}{l}\text { Frequency } \\
(\%)\end{array}$ & Reference \\
\hline 48 & $\begin{array}{l}\text { Southeast } \\
\text { (São Paulo) }\end{array}$ & 33.0 & 6 \\
\hline 34 & $\begin{array}{l}\text { Southeast } \\
\text { (Rio de Janeiro) }\end{array}$ & 35.0 & 7 \\
\hline 120 & $\begin{array}{l}\text { South } \\
\text { (Rio Grande do Sul) }\end{array}$ & 49.0 & 8 \\
\hline 48 & $\begin{array}{l}\text { South } \\
\text { (Santa Catarina) }\end{array}$ & 27.0 & 8 \\
\hline 34 & $\begin{array}{l}\text { South } \\
\text { (Paraná) }\end{array}$ & 44.0 & 8 \\
\hline 116 & $\begin{array}{l}\text { Southeast } \\
\text { (São Paulo) }\end{array}$ & 52.0 & 8 \\
\hline 62 & $\begin{array}{l}\text { Southeast } \\
\text { (Minas Gerais) }\end{array}$ & 53.0 & 8 \\
\hline 120 & $\begin{array}{l}\text { Southeast } \\
\text { (São Paulo) }\end{array}$ & 31.7 & 9 \\
\hline 122 & $\begin{array}{l}\text { South } \\
\text { (Rio Grande do Sul) }\end{array}$ & 50.8 & 10 \\
\hline 88 & $\begin{array}{l}\text { Southeast } \\
\text { (Rio de Janeiro) }\end{array}$ & 30.7 & 11 \\
\hline 320 & $\begin{array}{l}\text { Southeast } \\
\text { State? }\end{array}$ & 48.4 & 12 \\
\hline 154 & $\begin{array}{l}\text { South } \\
\text { (Rio Grande do Sul) }\end{array}$ & 48.7 & 13 \\
\hline 310 & $\begin{array}{l}\text { South/ Southeast } \\
\text { (Euro-Brazilians) }\end{array}$ & $81.0 *$ & 14 \\
\hline 76 & $\begin{array}{l}\text { South/ Southeast } \\
\text { (Afro-Brazilians) }\end{array}$ & $21.0 *$ & 14 \\
\hline
\end{tabular}

*The percentage refers to the overall frequency of the 70 most common CF mutations (not only $\Delta \mathrm{F} 508$ mutations). 
Figure 1 shows the detection of PCR products in $8 \%$ polyacrylamide gels. Homozygous patients (ho) have two 95 bp products, indicating 2 alleles with the $\Delta$ F508 mutation; heterozygous ones (he) have one 95 bp product one 98 bp product, indicating one $\Delta$ F508-mutated allele and one non-carrier (wild type) allele; and finally non-affected individuals or non-carriers (nc) have two 98 bp products, indicating 2 non-mutated alleles. The molecular weight marker used is the 25 bp marker from Invitrogen (USA).

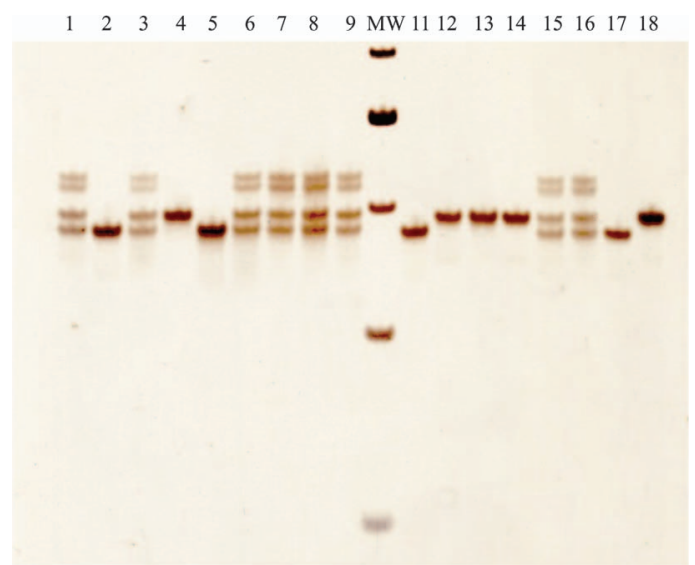

Figure 1 - Detection of $\triangle \mathrm{F} 508$ mutation by PCR in $8 \%$ polyacrylamide gels. Lanes 1, 3, 6, 7, 8, 9 and 15 are heterozygous patients (one 98 bp fragment and one $95 \mathrm{bp}$ one). Lanes 2, 5 and 11 are homozygous patients (two 95 bp fragments), and lanes 4, 12, 13 and 14 are noncarrier patients (two $98 \mathrm{bp}$ fragments). Lane 16 presents the heterozygous control, lane 17 the homozygous control and lane 18 the non-carrier control. Molecular weight (MW) is the $25 \mathrm{bp}$ molecular weight marker (Invitrogen, USA). The $5 \mathrm{MW}$ fragments are (from top to bottom): $150 \mathrm{bp}, 125 \mathrm{bp}, 100 \mathrm{bp}, 75 \mathrm{bp}$ and $50 \mathrm{bp}$.

\section{DISCUSSION}

The frequency of $\Delta \mathrm{F} 508$-mutated alleles in the present study was $44.5 \%$. This frequency is higher than the $33.0 \%$ and the $35.0 \%$ described by Martins et al. $(1993)^{6}$ and De Miranda et al. (1993) ${ }^{7}$, respectively, but it is noteworthy that they studied a limited number of patients (24 in São Paulo and 17 in Rio de Janeiro). However, Parizotto et al. (1997) ${ }^{9}$ studied 120 chromosomes from $60 \mathrm{CF}$ patients of the State of São Paulo and reported that only $31.7 \%$ of them had $\Delta$ F508-mutated alleles. Similarly, Cabello et al. (1999) described a frequency of $30.68 \%$ of alleles with the $\Delta$ F508 mutation in 88 patients from the State of Rio de Janeiro. ${ }^{11}$ On the contrary, Raskin et al. $(1993)^{8}$ studied 190 patients from the south and the southeast of Brazil: 60 from Rio Grande do Sul, 24 from Santa Catarina, 17 from Paraná, 58 from São Paulo and 31 from Minas Gerais. They found an overall frequency of $47.0 \%$ of alleles with the $\Delta$ F508 mutation. However, when the frequencies were considered according to the state of origin of patients, they found $49.0 \%$ in Rio Grande do Sul, 27.0\% in Santa Catarina, $44.0 \%$ in Paraná, $52.0 \%$ in São Paulo and $53.0 \%$ in Minas Gerais. In addition, Bernardino et al. (2000) $)^{12}$ and Streit et al. (2003) ${ }^{13}$ found higher frequencies of alleles with the $\Delta \mathrm{F} 508$ mutation that were very similar ( $48.4 \%$ and $48.7 \%$, respectively), but the former study did not mention whether the patients were all from the State of São Paulo, and the latter was carried out in the State of Rio Grande do Sul, in the south region of Brazil. Raskin et al. in a series of articles that analyzed the frequency of the $\Delta \mathrm{F} 508$ mutation as well as other common mutations associated with CF in Brazilian patients ${ }^{19,20,14}$ initially cited a frequency of $47.0 \%$ in Brazilian patients of European origin, ${ }^{19}$ then a frequency ranging from 30.7 to $50.8 \%,{ }^{20}$ and finally a striking difference in a screening for the 70 most common CF mutations (including $\Delta \mathrm{F} 508$ ) between Euro-Brazilians $(75.0 \%)$ and Afro-Brazilians $(21.0 \%){ }^{14}$

It is interesting to point out that in all polyacrylamide gels that were performed on heterozygous samples, 2 fragments of molecular weights between $100 \mathrm{bp}$ and $125 \mathrm{bp}$ were present. This phenomenon has already been observed and reported, ${ }^{21}$ but the relevance of these DNA fragments has still to be investigated. Nevertheless, these spurious fragments act as DNA markers for alleles that are heterozygous for the $\Delta \mathrm{F} 508$ mutation.

The present study added 216 chromosomes to the list of 1,652 already investigated in Brazilian CF patients with respect to the $\Delta \mathrm{F} 508$ mutation, of which only 284 alleles are certain to belong to patients of the State of São Paulo. The $44.45 \%$ of $\Delta$ F508-mutated alleles cited in the present study is within the range of frequencies already reported. Furthermore, all performed Brazilian studies (including ours) tend to indicate a lower frequency of $\Delta \mathrm{F} 508$-mutated alleles in Brazil in comparison to European and North American studies (around 70.0\%). This is probably due to the higher genetic heterogeneity of our population. These results emphasize the need to re-evaluate the cost vs. benefit ration regarding DNA-based tests for genetic screening in highly heterogeneous populations such as the Brazilian because they will be surely less effective in detecting $\Delta F 508$ mutations as well as in other common CF mutations.

\section{RESUMO}

OKAY TS e col. Frequiência da mutação $\Delta$ F508 em 108 pacientes com fibrose cística de São Paulo: comparação com dados de estudos brasileiros. CLINICS 60(2):131-134, 2005.
OBJETIVO: Analisar a freqüência da mutação delta F508 ( $\Delta$ F508) em 108 pacientes não aparentados, com fibrose cística e comparou os resultados com os dados de 
outros estudos brasileiros. A fibrose cística $(\mathrm{CF})$ constitui a doença genética mais comum em populações caucasianas, sendo a $\Delta \mathrm{F} 508$ a mais freqüente dentre as mutações relacionadas à doença.

MÉTODO: A freqüência da $\Delta$ F508 foi analisada por meio da Reação em Cadeia da Polimerase (PCR) seguida de detecção em géis de poliacrilamida a $8 \%$.

RESULTADOS: Vinte e três dos 108 pacientes foram homozigotos para a mutação $(21,3 \%), 50$ foram heterozigotos $(46,3 \%)$ e os 35 restantes não eram portadores da $\Delta \mathrm{F} 508(32,4 \%)$. Em termos de alelos, foram observados 96 mutados $(44,45 \%)$ e 120 do tipo selvagem $(55,55 \%)$, ou seja, não portadores da mutação.
CONCLUSÃO: A freqüência de 44,45\% de alelos mutados encontrada no estudo é mais elevada que os $33,0 \%$ descritos em pesquisa realizada em São Paulo em 1993, e ligeiramente mais baixa que os $48,0 \%$ encontrados em relatos mais recentes. Além disso, nossos resultados corroboraram a idéia de que a frequiência da mutação $\Delta$ F508 é mais baixa no Brasil em comparação a países europeus e nos Estados Unidos da América (cerca de 70,0\%), provavelmente devido a maior miscigenação racial. Estas observações terão que ser consideradas antes da implementação de testes genéticos de triagem no Brasil.

UNITERMOS: CFTR. $\Delta$ F508. Mutação. Deleção. Fibrose cística.

\section{REFERENCES}

1. Welsh M, Smith AE. Molecular mechanisms of CFTR: chloride channel dysfunction in cystic fibrosis. Cell 1993;73:1251-4.

2. Noone PG, Olivier KN, Knowles MR. Modulation of the ionic milieu of the airway in health and disease. Annu Rev Med 1994;45:421-34.

3. Riordan JR, Rommens JM, Kerem B, Alon N, Rozmahel K, Grzelczak Z, et al. Identification of the cystic fibrosis gene: cloning and characterization of complementary DNA. Science 1989;245:1066-73.

4. Tsui LC, Buchwald M. Cystic fibrosis. Ann Med Genet 1992;24:192245.

5. Tsui LC. The spectrum of cystic fibrosis mutations. Trends Genet 1992;8:392-8.

6. Martins CS, Ribeiro F, Costa FF. Frequency of the cystic fibrosis delta F508 mutation in a population from the State of São Paulo, Brazil. Braz J Med Biol Res 1993;26:1037-40.

7. De Miranda AB, Llerena Júnior J, Dallalana LT, Moura-Neto RS, Suffys PN, Degrave WM. Use of PCR for the determination of the frequency of the delta F508 mutation in Brazilian cystic fibrosis patients. Mem Inst Oswaldo Cruz 1993;88:309-12.

8. Raskin S, Philllips JA, Krishnamani MR, Unencak-Jones C, Parker RA, Dewsen E, et al. Regional distribution of cystic fibrosislinked DNA haplotypes in Brazil: Multicenter Study. Hum Biol 1997;69:75-88.

9. Parizotto EA, Bertuzzo CS, Ribeiro AF. Molecular characterization of cystic fibrosis patients in the state of São Paulo. J Med Genet $1997 ; 34: 877-81$.

10. Maróstica PJ, Raskin S \& Abreu-e-Silva FA. Analysis of the delta F508 mutation in a Brazilian cystic fibrosis population: comparison of pulmonary status of homozygotes with other patients. Braz J Med Biol Res 1998;31:529-32.

11. Cabello GM, Moreira AF, Horovitz D, Correia P, Santa Rosa A, Llerena Jr, et al. Cystic fibrosis: low frequency of DF508 mutation in 2 population samples from Rio de Janeiro, Brazil. Hum Biol 1999;71:189-96.
12. Bernardino AL, Ferri A, Passos-Bueno MR, KIM CE, Nakaie CM, Gomes CE, et al. Molecular analysis in Brazilian cystic fibrosis patients reveals five novel mutations. Genet Test 2000;4:6974.

13. Streit C, Burlamaque-Neto AC, De Abreu e Silva F, Giugliani R, Saraiva Pereira ML. CFTR gene: molecular analysis in patients from the South Brazil. Mol Genet Metabol 2003;78:259-64.

14. Raskin S, Pereira L, Reis F, Rosario NA, Ludwig N, Valentim L, et al. High allelic heterogeneity between Afro-Brazilians and EuroBrazilians impacts cystic fibrosis genetic testing. Genetic Testing 2003;7(3):213-8.

15. Miller AS, Dykes DD, Polesky HF. A simple salting out procedure for extracting DNA from human nucleated cells. Nucleic Acids Res 1988;16:1215.

16. Saiki Rk, Scharf S, Faloona F, Mullis Kb, Horn Gt, Erlich HA, et al. Enzymatic amplification of beta-globin genomic sequences and restriction site analysis for diagnosis of sickle cell anemia. Science 1985;230:1350-54.

17. Saiki RK, Gelfand DH, Stoffel S, Scharf SJ, Higuchi R, Horn GT, et al. Primer-directed enzymatic amplification of DNA with a thermostable DNA polymerase. Science 1988;239:487-91.

18. Bassam BJ, Caetano-Anollés G, Gresshoff PM. Fast and sensitive silver staining of DNA in polyacrylamide gels. Anal Biochem 1991;196:80-3.

19. Raskin S, Phillips JA, Kaplan G, McClure M, Vnencak-Jones C, Rozov T, et al. Geographic heterogeneity of 4 common worldwide cystic fibrosis non-DF508 mutations in Brazil. Hum Biol 1999;71(1):111-121.

20. Goloni-Bertollo EM, Rossit AR, Junior JB, Fett-Conte AC, Raskin S. CFTR molecular analysis reveals infrequent allele frequencies in nine cystic fibrosis patients from São Paulo State, Brazil Hum Biol 2003; 75(3):393-8.

21. Chong GL, Thibodeau SN. A simple assay for the screening of the cystic fibrosis allele in carriers of the Phe508 deletion mutation. Mayo Clin Proc 1990;65:1072-6. 